\title{
PREVALENCE OF TRACHOMA AMONG DISPLACED PERSONS IN THE SUDAN: A CLINICAL AND SERO-EPIDEMIOLOGICAL STUDY
}

\author{
EIGAALI A. MAHMOUD', A. H. SHEIKH ${ }^{2}$, M. A. DOMEIKA' ${ }^{\prime}$ and P. -A. MÅRDH ${ }^{1}$ \\ Uppsala, Sweden and Khartoum, The Sudan
}

\begin{abstract}
SUMMARY
The prevalence of trachoma was determined among displaced persons from the north, west and south of The Sudan who had settled in Angola Village, Omdurman County. Of 616 persons examined, $376(61 \%)$ were found to have clinical signs of active trachoma. Of the 448 children, aged 4 months to 15 years, $55(12 \%)$ had mild, 69 (15\%) moderately severe, and 210 (47\%) severe disease. The corresponding figures for those aged 16 and older (adults) were $5(3 \%), 12(7 \%)$ and $25(15 \%)$, respectively. The prevalence of active trachoma among the children in the village was $75 \%$, being higher among those from southern $(86 \%)$ Sudan than for those from the northern $(64 \%)$ and western $(66 \%)$ regions. The corresponding figures for the adults were $25 \%, 38 \%, 13 \%$ and $14 \%$. Antibodies to Chlamydia trachomatis were found in the lachrymal fluid of $224(67 \%)$ and in the serum of 272 $(81 \%)$ of the children tested. A higher $(74 \%)$ prevalence rate of antibody-positive tears was found in children from the south than from either northern $(58 \%)$ or western $(61 \%)$ Sudan. The corresponding percentages of antibody-positive sera were $90 \%, 72 \%$ and $73 \%$. In the adults, antibodies to $C$. trachomatis were found in tears of $28(67 \%)$. As in the children, the proportion of adults with antibody-positive tears was higher among those from the south $(80 \%)$ ) than in those from north or west Sudan ( $25 \%$ and $38 \%$, respectively). This was also true of the prevalence of serum antibodies, which was $93 \%$ versus $75 \%$ and $75 \%$, respectively. Trachoma is still common in The Sudan among persons of low socio-economic status. Our investigations also showed that the prevalence can differ between ethnic groups originating from different regions in spite of them having lived in the same place, often for years, and under the same primitive and trachoma-promoting conditions. Close family ties thus seem to be of greater importance in the prevalence of trachoma than do environmental conditions.
\end{abstract}

From: 'Institute of Clinical Bacteriology, University of Uppsala, Sweden: ${ }^{2}$ Department of Ophthalmology, University of Khartoum. The Sudan.

Correspondence to: Elgaali A. Mahmoud, Institute of Clinical Bacteriology, University of Uppsala, Box 552, S-75122 Uppsala. Sweden.
In many countries, trachoma is the chief cause of visual impairment and of preventable blindness. It is believed to affect some 200-300 million people worldwide, of whom approximately 5-10 million have become blind.'

High prevalences of trachoma have been recorded in certain parts of Africa: $50-91 \%$ in Ethiopia, ${ }^{2} 60 \%$ in TanZania, ${ }^{3} 16-35 \%$ in Egypt, ${ }^{+} 76 \%$ in Tunisia, ${ }^{5-7}$ and $82 \%$ in South Africa. ${ }^{\circ}$ In Saudi Arabia a prevalence of trachoma of $36 \%$ in the young beduin population ${ }^{9.10}$ was reported. Studies in Abu Dhabi showed a prevalence of $60.1 \% .^{11}$ In East Jerusalem the prevalence was $6.4 \%$, while it was as high as $77 \%$ in the Gaza Strip.' In some of these countries, however, the prevalence of trachoma has decreased since the above-cited studies were performed.

In The Sudan, the first isolation of the trachoma agent (on embyronated hens' eggs) was made by Harper in the 1960s. ${ }^{13}$ Other studies ${ }^{14}$ from The Sudan reported a trachoma prevalence of $83 \%$ in the arid northern area and sub-Saharan regions of the country, as compared with $3.2 \%$ in the south. Subsequent studies have observed a lower prevalence of trachoma of $47 \% .^{15}$

The present study was undertaken to determine the occurrence of active trachoma and the extent of clinical ocular involvement in different ethnic groups in a village located in central Sudan that had settlers from many parts of the country.

\section{POPULATION AND METHODS}

\section{Study Locality and Population}

The study, which was performed in 1992, was confined to Angola Village, situated $25 \mathrm{~km}$ west of the city of Omdurman, The Sudan. This village was previously a camp for displaced persons who came there because of famine caused by drought in southern, western and northern Sudan. The village has about 10000 inhabitants, reasonably representative of different ethnic groups living in the above areas of The Sudan. The inhabitants generally had a very low standard of living. Angola Village was selected because it was relatively accessible by road (i.e. it had suitable conditions for quick transport of samples) and 


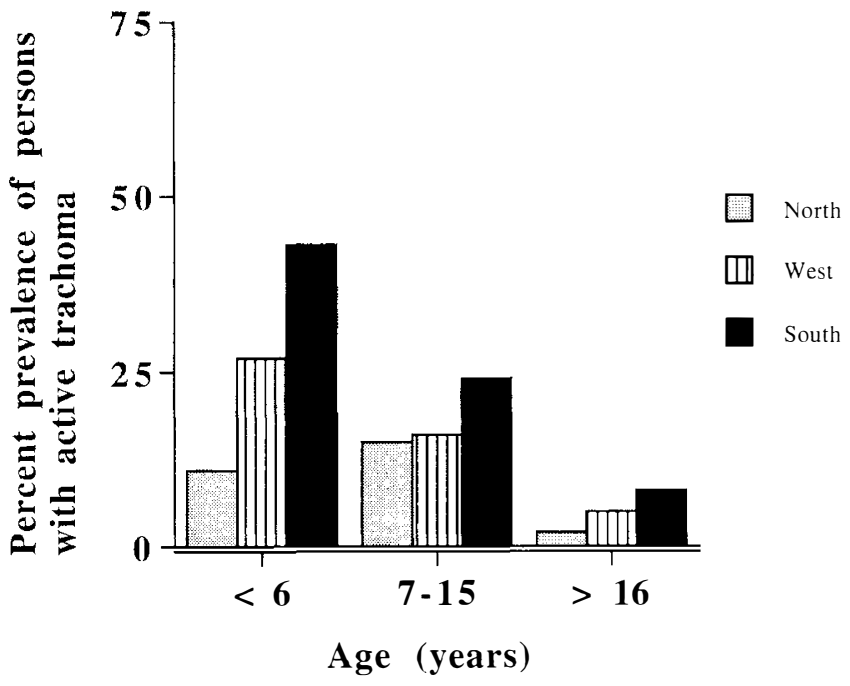

Fig. 1. Prevalence of active trachoma in Angola Village among persons originating from the north. west and south. according to age.

because it had not previously been involved in screening or therapeutic studies of trachoma.

Of the 616 persons studied in the age range 4 months to 56 years, 448 were children ( 124 girls and 324 boys, aged 4 months to 15 years with a median age of 7 years); of those classified as adults there were 52 females and 116 males (16-56 years old with a median age of 32 years).

\section{Clinical Examination}

The patients were examined by an ophthalmologist with a special interest in trachoma, with the aid of a hand lamp and a magnifying glass $(\times 2)$. Staging of trachoma disease was made according to MacCallan, as modified by a WHO expert committee. ${ }^{16}$ The intensity of upper tarsal disease was assessed using a modification of the grading system proposed by Dawson and co-authors.' Stages I, II and III correspond to mild, moderate and severe trachoma. Subjects with trachoma who showed signs of inflammation (follicles and papillary hypertrophy on the upper tarsal conjunctivae) were considered positive.

\section{Specimen Collection}

Lachrymal fluid was produced by stimulation of the nasal mucosa as previously described. ${ }^{17}$ The resulting reflex tears were aspirated into a $100 \mu \mathrm{l}$ capillary pipette. The secretion was collected carefully to avoid touching the conjunctiva. The capillary tubes were emptied of their contents by gently blowing the secretion into sterile glass vials, which were kept in boxes containing ice-packs for $3-4$ hours at the most before stored at $-70^{\circ} \mathrm{C}$ at the Bacteriological Laboratory, Khartoum Civil Hospital, until transport on dry ice to the Institute of Clinical Bacteriology at Uppsala University, Sweden.

Blood was collected in Vacutainers which were kept in the same boxes as the Chlamydia samples. At the laboratory, sera were separated and stored at $-20^{\circ} \mathrm{C}$ until transported frozen to Sweden.

Whereas the clinical examination was performed in all cases, tears and serum samples were collected only from subjects who had signs of active trachoma.

\section{Microimmunofluorescence Antibody Tests}

Antibodies to Chlamydia trachomatis were, with some minor modifications, studied by microimmunofluorescence (MIF) tests as described by Wang et al. ${ }^{18}$ Thus $C$. trachomatis antigen was applied to glass slides and fixed with acetone. The initial dilutions for $\operatorname{IgA}$ and $\operatorname{IgM}$ were $1: 8$, and $1: 16$ for $\operatorname{IgG}$. The samples were incubated in a moist chamber for 45 minutes at $37^{\circ} \mathrm{C}$ for the $\operatorname{IgG}$ and $\operatorname{IgA}$ antibody tests and 90 minutes for $\operatorname{IgM}$. The slides were washed twice in phosphate-buffered saline, rinsed in distilled water and left to air-dry. Fluorescein isothiocyanate (FITC)-conjugated rabbit anti-human globulins (Dakopatts, Copenhagen) were added, after which the slides were incubated (45 minutes and 90 minutes) and washed as described above. The MIF tests were read under a fluorescence microscope (Optiphot, Nikon).

\section{RESULTS}

Of the 616 persons examined, $376(61 \%)$ had clinical signs of active trachoma. The prevalence rates of trachoma in persons (or their parents) originating from different parts of The Sudan are shown in Fig. 1.

Of the 448 children, 334 (75\%) had active trachoma. The highest prevalence $(86 \%)$ was found among those from the south of The Sudan, compared with $64 \%$ among those from the north and $66 \%$ among those from the west. The highest prevalence $(63 \%)$ of severe disease was found among those from the south. The prevalence of severe inflammatory disease was significantly lower $(p>0.05)$ among those (or their parents) from the north $(33 \%)$ and west $(35 \%)$ of The Sudan. Preschool children from the south had a higher rate $(43 \%)$ of active disease than those from northern (11\%) and western regions (27\%) (Fig. 2).

The overall prevalence of active trachoma in those 16 years or older was $25 \%$, being highest among people from the south $(38 \%)$. Prevalence was similar among people from northern (13\%) and western (14\%) Sudan (Fig. 3).

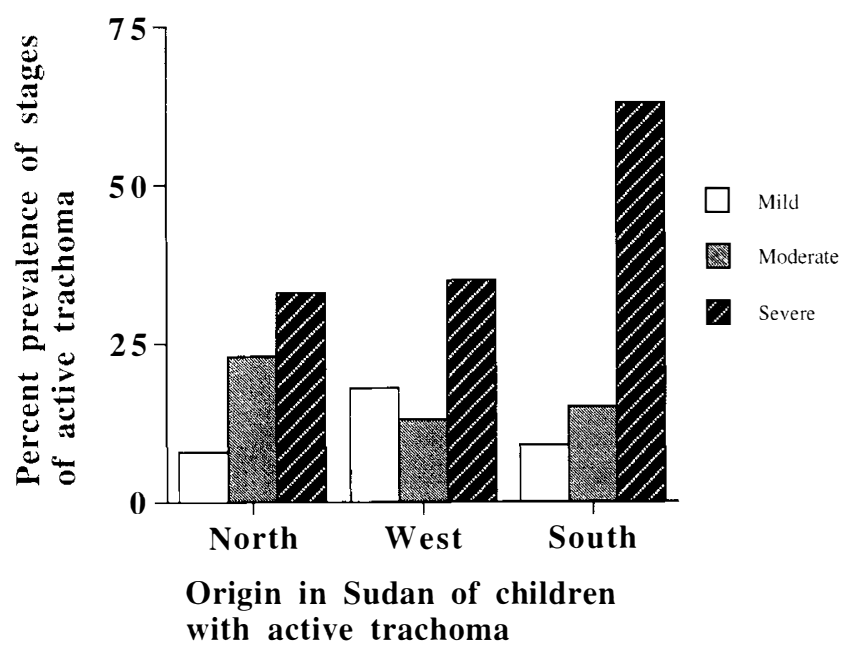

Fig. 2. Prevalence of stages of active trachoma (mild, moderate, severe) in Angola Village among children. 


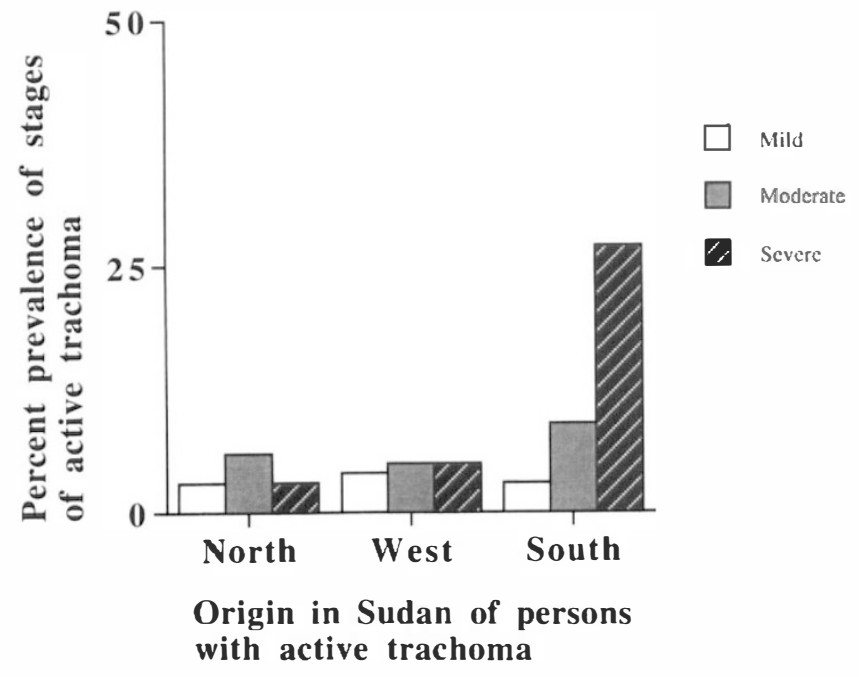

Fig. 3. Prevalence of stages of active trachoma (mild, moderate, severe) in Angola Village among adults.

The prevalence rates of serum and tear antibody to $C$. trachomatis among children and adults are illustrated in Table I. Antibodies to C. trachomatis in lachrymal fluid were found in 224 of the $344(67 \%)$ children and in serum from $272(81 \%)$ of them. The highest prevalence of antibodies to C. trachomatis in tears (74\%) and serum (90\%) was found among children from the south. Of the children from the north, $31(58 \%)$ had antibody-positive tears, while $38(72 \%)$ had a positive serum sample. The corresponding figures for those from the west were $66(61 \%)$ and $80(73 \%)$, respectively.

In the adults, antibodies to $C$. trachomatis were found in lachrymal fluid from $28(67 \%)$ and in serum from 37 $(88 \%)$. The antibody prevalence was higher among persons with active disease 16 years or older (or their parents) who had come from the south, i.e. $24(80 \%)$ had tear antibodies and $28(93 \%)$ serum antibodies. In those from the north with active disease the corresponding figures were 1 and 3, while in those from the west they were 3 and 6 (Table I).

IgG antibodies to $C$. trachomatis were found in lachrymal fluid from $260(78 \%)$ of the children and IgA antibodies in $91(27 \%)$. Serum IgG and IgM antibodies were found in $269(80 \%)$ and $47(14 \%)$ of the children respectively. The corresponding percentages for persons 16 years or older were $86 \%, 29 \%, 93 \%$ and $10 \%$ (Tables II, III).

Table I. Prevalence of tear and serum antibodies to Chlamydia trachomatis among children and adults in Angola Village originating from various parts of the Sudan

\begin{tabular}{|c|c|c|c|c|c|c|}
\hline \multirow{3}{*}{$\begin{array}{l}\text { Persons } \\
\text { originating } \\
\text { from }\end{array}$} & \multicolumn{3}{|c|}{ Children } & \multicolumn{3}{|c|}{ Adults } \\
\hline & \multirow{2}{*}{$\begin{array}{c}\text { No. } \\
\text { examined }\end{array}$} & \multicolumn{2}{|c|}{$\begin{array}{l}\text { No. (\%) with } \\
\text { antibodies in }\end{array}$} & \multirow{2}{*}{$\begin{array}{c}\text { No. } \\
\text { examined }\end{array}$} & \multicolumn{2}{|c|}{$\begin{array}{l}\text { No. (\%) with } \\
\text { antibodies in }\end{array}$} \\
\hline & & Tears & Serum & & Tears & Serum \\
\hline North & 83 & $31(58)$ & $38(72)$ & 32 & $1(25)$ & $3(75)$ \\
\hline West & 165 & $66(61)$ & $80(73)$ & 57 & $3(38)$ & $6(75)$ \\
\hline South & 200 & $127(74)$ & $154(90)$ & 79 & $24(80)$ & $28(93)$ \\
\hline Total & 448 & $224(67)$ & $272(81)$ & 168 & $28(67)$ & $37(88)$ \\
\hline
\end{tabular}

Table II. Prevalence of tear and serum antibodies to Chlamydia tra(homatis (of different Ig classes) among children in Angola Village

\begin{tabular}{|c|c|c|c|c|c|}
\hline \multirow{3}{*}{$\begin{array}{l}\text { Children } \\
\text { originating } \\
\text { from }\end{array}$} & \multirow{3}{*}{$\begin{array}{l}\text { No. } \\
\text { tested }\end{array}$} & \multicolumn{4}{|c|}{ No. (\%) with antibodies in } \\
\hline & & \multicolumn{2}{|c|}{ Tears } & \multicolumn{2}{|c|}{ Serum } \\
\hline & & $\operatorname{IgG}^{a}$ & $\operatorname{IgA}^{\mathrm{h}}$ & $\mathrm{IgG}$ & $\operatorname{IgM}^{c}$ \\
\hline North & 53 & $46(87)$ & $13(25)$ & $48(90)$ & $6(11)$ \\
\hline West & 109 & $59(54)$ & $21(19)$ & $63(58)$ & $13(12)$ \\
\hline South & 172 & $155(90)$ & $57(33)$ & $158(92)$ & $28(16)$ \\
\hline Total & 334 & $260(78)$ & $91(27)$ & $269(81)$ & $47(14)$ \\
\hline
\end{tabular}

"Titre at $1: 8$ : "titre $\geqslant 1: 16$ : "titre at $1: 8$.

Onchocerciasis was found in 18 persons from the south, all of whom were adults. None of those from the west or north suffered from this disease.

\section{DISCUSSION}

Trachoma was found to be hyperendemic in Angola Village. The population studied came from different regions of The Sudan, i.e. from the north (Sahara), from the west (sub-Sahara) and from the south (equatorial Africa), that have different morbidity rates of trachoma. The villagers (or their parents) had at some time in the past been displaced due to famine and drought in their native region. The study population had mostly been living in Angola Village for years under the same environmental conditions.

Previous studies on trachoma in The Sudan have generally focused on socio-economic factors. ${ }^{19}$ Salim and Sheikh ${ }^{14}$ found a higher $(83 \%)$ prevalence of trachoma in northern and western Sudan than in the south $(3.2 \%)$. In the northern parts of the Sudan a high trachoma prevalence seems paradoxical, since cultural and religious traditions in these areas favour personal cleanliness, as compared with the south where the hygiene and socioeconomic conditions are much less favourable.

The area where Angola Village is situated has hot summers with a mean day temperature of $38^{\circ} \mathrm{C}$, a mean relative humidity of about $40 \%$ at a certain time of the day (8.00 a.m.), and an annual rainfall of $300 \mathrm{~mm}$. There are frequent sandstorms between June and October. The dwellings are built of earth (mud). The village is heavily fly-infested in the rainy season, i.e. from June to October. There is no electricity and no running water. The only communal pump is $3 \mathrm{~km}$ from the village. Standards of

Table III. Prevalence of tear and serum antibodies to Chlamydia trachomatis among persons 16 years or older in Angola Village

\begin{tabular}{|c|c|c|c|c|c|}
\hline \multirow{3}{*}{$\begin{array}{l}\text { Persons } \\
\text { originating from }\end{array}$} & \multirow{3}{*}{$\begin{array}{l}\text { No. } \\
\text { tested }\end{array}$} & \multicolumn{4}{|c|}{ No. $(\%)$ with antibodies in } \\
\hline & & \multicolumn{2}{|c|}{ Tears } & \multicolumn{2}{|c|}{ Serum } \\
\hline & & $\operatorname{IgG}^{a}$ & $\operatorname{Ig}^{\mathrm{b}}$ & $\operatorname{IgG}$ & $\operatorname{IgM}^{\mathrm{c}}$ \\
\hline North & 4 & $3(75)$ & $1(25)$ & $4(100)$ & 0 \\
\hline West & 8 & $6(75)$ & $2(25)$ & $7 \quad(88)$ & $1(13)$ \\
\hline South & 30 & $27(90)$ & $9(30)$ & $28 \quad(93)$ & $3(10)$ \\
\hline Total & 42 & $36(86)$ & $12(29)$ & $39 \quad(93)$ & $4(10)$ \\
\hline
\end{tabular}

"Titre at $1: 8 ;{ }^{\mathrm{b}}$ titre $\geqslant 1: 16$; ${ }^{\mathrm{c}}$ titre at $1: 8$. 
personal and communal hygiene are very poor. Water is used mainly for cooking purposes. Many of the abovementioned factors have been implicated in promoting the spread of trachoma.

Onchocerciasis is common in Angola Village - but only among adults who have acquired the disease in the south of The Sudan. Acute bacterial conjunctivitis is also prevalent (with the highest incidence during June to December). Whether these two conditions also promote the establishment of trachoma seem to have been little studied.

The overall prevalence of active trachoma in Angola Village was $75 \%$ in the children and $25 \%$ in the adults, which is in the higher range of previously reported prevalence figures from various Sudanese localities. ${ }^{15}$

There was a higher prevalence of active trachoma among people who had migrated to Angola Village from the south than among those from north and west (Tables I, II). In people (or their offspring) from the Sahara and subSahara, the prevalences were lower even though they came from dusty, arid regions. This was true for those who were over 10 years old and had been born outside the village. The same skew distribution in prevalence among the younger children and their parents is noteworthy, as they all shared similar environmental and socio-economic conditions. This difference in prevalence of active trachoma in the children was similar to that of their parents.

Variations in susceptibility to $C$. trachomatis eye infection as well as the severity and rate of sequelae of trachoma has been related to, among other things, racial differences. ${ }^{20}$ In the present study, racial diversity was found between those from the south (Nilotics), the north (Arabs) and the west (Nubians). Confounding factors might have been of greater importance than race alone in explaining the differences. The number of individuals per household (in each individual's 'closed community') in Angola Village was the same in the different ethnic groups, so could not have contributed to the difference in prevalences. These differences may be explained in terms of family ties, e.g. eating and sleeping together, often sharing the same bed. It seems that people in The Sudan have been rather unaffected in their habits by migration.

The prevalence of detectable antibodies to C. trachomatis among children in Angola Village was 67\% in tear fluids and $81 \%$ in the serum samples. The corresponding prevalence rates for the adults were $67 \%$ and $88 \%$ respectively. These figures for antibody positivity are among the highest reported from The Sudan. ${ }^{1+.15}$

Our clinical and sero-epidemiological data do not suggest any reduction in the trachoma disease problem in the area studied; this is in contrast to reports from many other parts of the world, particularly where the socio-economic and hygiene conditions have improved, along with improved access to health care. In Angola Village no medical intervention programmes had been undertaken to reduce the prevalence of trachoma.

Key words: Anti-chlamydial antibody, Displaced persons, Trachoma.

\section{REFERENCES}

1. Dawson CR, Jones BR, Tarrizo ML. Guide to trachoma control in programmes for the prevention of blindness. Geneva: WHO, 1981:38-47.

2. Cerulli L, Cedrone C, Cullaso F, Martelli M, Tria M. Epidemiological study on trachoma in two regions of Ethiopia. Rev Int Trach Pathol Ocul Trop Subtrop 1981;3:147-55.

3. West ST, Munoz B, Turner VM, Mmbaga BB, Taylor HR. The epidemiology of trachoma in central Tanzania. Int J Epidemiol 1991;20:1088-92.

4. Barsoum IS, Mostafa MS, Shihab AA, El Alamy M. Habib MA, et al. Prevalence of trachoma in school children and ophthalmological outpatients in rural Egypt. Am J Trop Med Hyg 1987;36:97-101.

5. Dawson CR, Daghfous T, Massadi M, Hoshiwara I, Schachter J. Severe endemic trachoma in Tunisia. Br J Ophthalmol 1976:60:245-52.

6. Hanna L, Jawetz N, Briones O, Ostler H, Keshishyan H, et al. Antibodies to TRIC agents in matched human tears and sera. J Immunol 1973;1 10:1464-9.

7. Treharne JD, Dwyer RS, Darougar S, Jones BR. Daghfous T. Antichlamydial antibody in tears and sera, and serotypes of Chlamydia trachomatis isolated from schoolchildren in Southern Tunisia. Br J Ophthalmol 1978;62:509-15.

8. Ballard RC, Fehler HG, Baerveldı G, Owen G, Sutter EE, et $a l$. The epidemiology and geographical distribution of trachoma in Lebowa. S Afr Med J 1981;60:531-5.

9. Bobb AA, Nichols RL. Influence of environment on clinical trachoma in Saudi Arabia. Am J Ophthalmol 1969;67: $235-43$.

10. McComb DE, Nichols R. Antibodies to trachoma in eye secretions of Saudi Arab children. Am J Epidermiol 1969; 90:278-84.

11. Majcuk JF. Trachoma treatment in areas of high prevalence. Rev Int Trach Pathol Ocul Trop Subtrop 1973;50:55-66.

12. Bishara S, Yanko L. Prevalence of trachoma among children in East Jerusalem in 1980. Br J Ophthalmol 1982;66:580-2.

13. Harper IA. Trachoma in the Sudan. Lancet 1963;2:438-9.

14. Salim AR, Sheikh HA. Trachoma in The Sudan: an epidemiological study. Br J Ophthalmol 1975;59:600-4.

15. Elbagir A, Mårdh P-A. Evaluation of chlamydial tests in early trachoma. APMIS 1990;98:276-80.

16. WHO. Scientific group on trachoma research. WHO Tech Rep Ser 1966:330:20.

17. Robert N, James J, Feldman R, Linsy F, Irwin DM. The effect of collection technique on tear composition. Invest Ophthalmol 1984;25:374-7.

18. Wang S-P, Grayston JT, Alexander ER, Holmes KK. Simplified microimmunofluorescence test with trachoma-lymphogranuloma venereum (Chlamydia trachomatis) antigen for use as a screening test for antibody. J Clin Microbiol 1975;1: $250-5$.

19. Majcuk JF. A study of trachoma and associated infections in the Sudan. Bull WHO 1966:35:262-72.

20. Mann I. Culture, race, climate and eye disease. Springfield, Illinois: Charles C. Thomas, 1966:428-44. 